\title{
Science through Sepedi: Is Terminologisation a Worthwhile Venture?*
}

\author{
Adelia Carstens, Department of Afrikaans, \\ University of Pretoria, Pretoria, Republic of South Africa
}

\begin{abstract}
The terminologisation of the African languages has been hotly debated for more than a decade, yet little progress has been made in devising strategies to guide this process. The following are among the indicators that the time is ripe to realise the ideal of terminologisation: the lack of success thus far achieved in facilitating scientific knowledge through non-mother-tongue education; the existence of a noteworthy stock of technical terms in the African languages; and the positive attitudes of educators towards the use of the mother tongue, especially in rural areas. These indicators are backed up by statistics on pass rates for Physical Science in the Northem Province; the results of an attitude/opinion survey among teachers of Science in this region; lexical data obtained from an empirical survey as well as from an independent source. The results of the research seem to validate terminologisation of Sepedi from an educational point of view. It is, however, realised that the attitudes and perceptions of other stakeholders such as pupils and parents need to be taken into account when recommendations are made with regard to sensitive issues such as terminologisation and the language of scientific communication.
\end{abstract}

Keywords: AFRICAN LANGUAGES, LANGUAGE DEVELOPMENT, LANGUAGE FOR SPECIAL PURPOSES, MOTHER-TONGUE EDUCATION, MULTILINGUALISM, NORTHERN SOTHO, PHYSICAL SCIENCE, SCIENTIFIC LANGUAGE, SEPEDI, TERMINOGRAPHY, TERMINOLOGISATION, TERMINOLOGY

Opsomming: Wetenskap in Sepedi: Is terminologisering die moeite werd? Die terminologisering van die Afrikatale word al vir langer as 'n dekade druk bespreek. Tog is weinig vordering nog gemaak met betrekking tot die beplanning van algemene strategieë wat rigting aan hierdie proses kan gee. Daar is veral drie aanwysers dat die tyd ryp is om erns te maak met terminologisering: die min sukses wat tot dusver behaal is in die fasilitering van wetenskaplike kennis deur medium van niemoedertaalonderrig; die bestaan van 'n noemenswaardige korpus tegniese/wetenskaplike terme in die Afrikatale; en die positiewe gesindheid van wetenskaponderwysers teenoor die gebruik van die moedertaal, veral in landelike gebiede. Ter ondersteuning van hierdie aanduidings word die volgende getuienis aangebied: statistiek oor die slaagsyfers vir Natuurwetenskap in die Noordelike Provinsie, die uitslae van 'n houdingstudie / meningspeiling

A shortened version of this article was read as a paper at the Third International Conference of the African Association for Lexicography, held at the Potchefstroom University for Christian Higher Education, Potchefstroom, 29 June-1 July 1998. 
onder wetenskaponderwysers in hierdie gebied; leksikale gegewens wat sowel uit 'n empiriese ondersoek as van 'n onafhanklike bron verkry is. Vanuit ' $n$ opvoedkundige oogpunt blyk die resultate van die navorsing die terminologisering van Sepedi te staaf. Daar word egter besef dat die houdings en persepsies van ander rolspelers, bv. leerlinge en ouers, in berekening gebring moet word wanneer aanbevelings gemaak word oor sensitiewe kwessies soos die taal van wetenskapskommunikasie.

Sleutelwoorde: AFRIKATALE, MOEDERTAALONDERRIG, MEERTALIGHEID, NOORDSOTHO, NATUURWETENSKAP, SEPEDI, TAALONTWIKKELING, TAAL VIR SPESIALE DOELEINDES, TERMINOLOGIE, TERMINOGRAFIE, TERMINOLOGISERING, WETENSKAPSTAAL

\section{Introduction}

Terminologisation of the African languages has been hotly debated for more than a decade and numerous workshops, conferences, academic publications and seminars have been devoted to this topic or aspects thereof (cf. Cluver 1987, 1989; Matšela 1987; LANGTAG Subcommittee on the Development of (South) African Languages 1996; National Terminology Services 1997). Questions such as the following have been asked:

\section{(a) What are the aims of terminologisation in the African languages?}

In the terminologisation debate objectives and motivations such as the following have featured:

- functional elaboration, which will allow a speaker of any official South African language to use his/her language effectively in any context (Cluver 1989);

- full empowerment through the language which a speaker knows best (Ngubane 1997: 7);

- providing access to knowledge and allowing concept-formation in the language the speaker knows best (Mthembu 1997: 99);

- providing the opportunity to exercise democratic language rights (Ngubane 1997: 7-8);

- the compilation of technical defining dictionaries for each of the school subjects offered in the mother tongue at primary school level (Cluver 1996: 10); and

- facilitating mother-tongue education up to secondary and tertiary level (cf. Prah 1995, 1997; Mohapi 1997: 75; and Mthembu 1997: 99 who express their support, vs. Bekeweni 1997: 94 who expresses scepticism over the feasibility thereof in terms of the time and cost involved). 
Although these objectives can be separated, they overlap to a certain extent: common to them all is the ideal of "elevating" the African languages to the same functional level as English and Afrikaans, i.e. providing these languages and their speakers with the same opportunities and bestowing them with the same privileges that Afrikaans and English had enjoyed until 1994.

Should terminologisation reach a specific stage before the language(s) in question can be used as fully-fledged special languages for purposes such as instruction, publication, evaluation, etc.? Is it possible to address highly specialised topics such as nuclear physics, biochemistry, etc. in a language with no standardised (formally recorded) LSP for that subject field?

In metaphorical terms these two questions (cf. Carstens 1997: 6; Matšela 1987: 80; Bekeweni 1997: 94) may be rephrased as different philosophies serving as prerequisites for the use of a particular language as a scientific or technical language:

- All the necessary tools must be in place before construction can begin.

- Use what you have. That which you lack, can be borrowed or adapted along the way.

(c) Does terminologisation of the African languages form an integral part of the Government's language development programme?

The promotion of Science, Engineering and Technology (SET) is clearly one of the primary objectives of the present South African Government. These areas are characterised in the Green Paper on Science and Technology (s.a.) as the "absolutely vital components of economic and social progress". Access to these domains, as to most other domains in life, is provided through language, and if the linguistic code employed denies access rather than facilitates it, knowledge remains exclusive to the historically privileged. This fact is clearly realised by Government. In his opening address at a workshop entitled "The Feasibility of Technical Language Development in the African Languages" held in Pretoria on 8 March 1996, the Minister of Arts, Culture, Science and Technology, Dr B.S. Ngubane, made the following statement indicating the Government's recognition of the need for language development and the role it may play in the process of empowerment:

The vision we have for our country and the strategies to arrive at our goals depend on many factors, one of them being appropriate knowledge. Knowledge is power. Knowledge transfer can only take place if a person understands the concepts being conveyed to him or her and the context in which it takes place. Keeping in mind that people are a nation's greatest asset, development can only be fostered if people are 
developed. In this whole process, language plays the most important role (Ngubane 1997: 7).

A logical entailment of these words seems to be that if a person does not have full command of the language in which a concept is conveyed to him or her, conceptualisation will not be (fully) realised. However, the usefulness of the African languages in scientific and academic contexts is often articulated in rather tentative terms by Government spokespersons, i.e. without identifying personally with the particular goal. In an ensuing statement made by the above speaker, he expresses himself as follows:

It has been argued (my italics) that the development of South Africa first requires the development of the literacy of the people in their own mother tongues, which will assist them in developing skills in scientific and technical fields.

Although I strongly agree with Chumbow (1990: 65) that "all languages are capable of being developed (sufficiently rapidly) by the expansion of vocabulary to cope with any aspect of knowledge, including science and technology", there are still many South Africans who have to be convinced of this fact. For many, only hard scientific evidence will be recognised as the gunshot signifying the start of the race towards terminologisation.

The primary aim of this paper is then to indicate, on the basis of empirical research, that the development of the African languages as special languages for the full spectrum of scientific and technological disciplines is indeed feasible and advisable for the following reasons:

- the lack of success thus far achieved in facilitating scientific knowledge through non-mother-tongue education;

- the stock of technical terms that already exist in the African languages; and

- the positive attitude of educators regarding selective multilingualism (including the use of the mother tongue) in the classroom.

\section{Statistics on pass rates in Science}

The following statistics, obtained from the Department of Education of the Northern Province, provide alarming evidence regarding the matric results in Physical Science for 1996 and 1997. Among other tendencies indicated by the figures below (Manyane 1998: 10-13), they also indicate that the failure rate is much higher in schools where Science is not taught in the mother tongue ${ }^{1}$ (i.e. where English is used as the medium of instruction to teach Science to mothertongue speakers of Sepedi), than in schools where the medium of instruction corresponds with the mother tongue of the pupils: 


\section{NORTHERN PROVINCE, REGION 1 (WESTERN) AREA 2 (MAHWELERENG)}

$\begin{array}{lll} & 1996 & 1997 \\ \text { Number of schools: } & 34 \text { (2 Afrikaans, 32 Sepedi) } & 29 \text { (2 Afrikaans, 39 Sepedi) }\end{array}$

TABLE 1: Pass rates, Mahwelereng (Higher Grade and Standard Grade)

\begin{tabular}{|c|c|c|c|c|}
\hline Year & Level & $\begin{array}{c}\text { Total number of } \\
\text { candidates }\end{array}$ & $\begin{array}{c}\text { Number of candidates } \\
\text { passed }\end{array}$ & Percentage \\
\hline 1996 & HG & 420 & 75 & 17,9 \\
\hline & SG & 444 & 154 & 34,7 \\
\hline 1997 & HG & 382 & 169 & 44,2 \\
\hline & SG & 720 & 299 & 41,5 \\
\hline
\end{tabular}

TABLE 2: Symbols achieved for Physical Science in Mahwelereng (Higher Grade)

\begin{tabular}{|c|c|c|c|c|}
\hline Symbol & \multicolumn{2}{|c|}{$\begin{array}{c}\text { Number of candidates } \\
\text { (language of instruction: Afrikaans) } \\
\text { (mother tongue: Afrikaans) }\end{array}$} & $\begin{array}{c}\text { Number of candidates } \\
\text { (language of instruction: English) } \\
\text { (mother tongue: Sepedi) }\end{array}$ \\
\hline & 1996 & 1997 & 1996 & 1997 \\
\hline A & 1 & 3 & 0 & 0 \\
\hline B & 6 & 5 & 0 & 0 \\
\hline C & 13 & 22 & 2 & 1 \\
\hline D & 14 & 12 & 7 & 8 \\
\hline E & 8 & 18 & 24 & 26 \\
\hline
\end{tabular}

TABLE 3: Symbols achieved for Physical Science in Mahwelereng (Standard Grade)

\begin{tabular}{|c|c|c|c|c|}
\hline Symbol & \multicolumn{2}{|c|}{$\begin{array}{c}\text { Number of candidates } \\
\text { (language of instruction: Afrikaans) } \\
\text { (mother tongue: Afrikaans) }\end{array}$} & \multicolumn{2}{|c|}{$\begin{array}{c}\text { Number of candidates } \\
\text { (language of instruction: English) } \\
\text { (mother tongue: Sepedi) }\end{array}$} \\
\hline A & 0 & 0 & 0 & 1 \\
\hline B & 4 & 2 & 1 & 1 \\
\hline C & 8 & 11 & 7 & 4 \\
\hline D & 9 & 12 & 28 & 27 \\
\hline E & 14 & 11 & 39 & 70 \\
\hline
\end{tabular}




\section{AREA 3 (WARMBATHS)}

$\begin{array}{lll} & 1996 & 1997 \\ \text { Number of schools: } & 11 \text { (4 Afrikaans, 7 Sepedi) } & \text { (3 Afrikaans, 8 Sepedi) }\end{array}$

TABLE 4: Pass rates, Warmbaths (Higher Grade and Standard Grade)

\begin{tabular}{|c|c|c|c|c|}
\hline Year & Level & $\begin{array}{c}\text { Total number of } \\
\text { candidates }\end{array}$ & $\begin{array}{c}\text { Number of candi- } \\
\text { dates passed }\end{array}$ & Percentage \\
\hline 1996 & HG & 314 & 126 & 40,1 \\
\hline & SG & 157 & 131 & 83,4 \\
\hline 1997 & HG & 192 & 108 & 56,3 \\
\hline & SG & 242 & 127 & 52,5 \\
\hline
\end{tabular}

TABLE 5: Symbols achieved for Physical Science in Warmbaths (Higher Grade)

\begin{tabular}{|c|c|c|c|c|}
\hline Symbol & \multicolumn{2}{|c|}{$\begin{array}{c}\text { Number of candidates } \\
\text { (language of instruction: Afrikaans) } \\
\text { (mother tongue: Afrikaans) }\end{array}$} & $\begin{array}{c}\text { Number of candidates } \\
\text { (language of instruction: English) } \\
\text { (mother tongue: Sepedi) }\end{array}$ \\
\hline & 1996 & 1997 & 1996 & 1997 \\
\hline A & 8 & 8 & 0 & 0 \\
\hline B & 9 & 6 & 1 & 1 \\
\hline C & 37 & 31 & 5 & 5 \\
\hline D & 31 & 17 & 2 & 10 \\
\hline E & 21 & 11 & 12 & 17 \\
\hline
\end{tabular}

TABLE 6: Symbols achieved for Physical Science in Warmbaths (Standard Grade)

\begin{tabular}{|c|c|c|c|c|}
\hline Symbol & $\begin{array}{c}\text { Number of candidates } \\
\text { (language of instruction: Afrikaans) } \\
\text { (mother tongue: Afrikaans) }\end{array}$ & \multicolumn{2}{|c|}{$\begin{array}{c}\text { Number of candidates } \\
\text { (language of instruction: English) } \\
\text { (mother tongue: Sepedi) }\end{array}$} \\
\hline & 1996 & 1997 & 1996 & 1997 \\
\hline A & 5 & 0 & 0 & 0 \\
\hline B & 3 & 6 & 4 & 1 \\
\hline C & 16 & 11 & 7 & 7 \\
\hline D & 30 & 30 & 12 & 14 \\
\hline E & 21 & 17 & 12 & 12 \\
\hline
\end{tabular}


Despite the changes in the various figures for Higher and Standard Grade that occurred from 1996 to 1997, the average for Physical Science remains below $50 \%$, and the students who had received mother-tongue education still achieved much higher symbols than those who had received non-mothertongue education. Although one cannot necessarily assign a causal relationship between medium of instruction and academic achievement (other variables may be inadequately trained teachers, low school attendance figures and lack of equipment) the correlation across different areas does merit research with regard to the use of language in the classroom and the possible impact this may have on conceptualisation. The research results may then indicate a course of action with regard to the development of languages and academic resources in South Africa.

\section{Sepedi as an LSP for Science: evidence from a survey among secon- dary school teachers}

During the course of 1997 I conducted a terminology research project in the Northern Province together with a Masters Degree student, Ms S.M. Manyane. Our main objectives were to establish :

(a) the status and frequency of Sepedi as an LSP for Science in this area;

(b) the attitudes and perceptions of one category of the role-players in the area, namely teachers of Physical Science;

(c) the scope and nature of the existing corpus of conventionalised and semi-conventionalised Science terms in Sepedi; and

(d) the feasibility of compiling translatory and explanatory tools (in the form of multilingual explanatory special-field dictionaries) in order to provide access to knowledge via the mother tongues of the pupils, as well as through English.

The research questions (focusing on (a)=(c)) were addressed as follows:

\subsection{Status and usage frequency of Sepedi as an LSP for Science}

During 199750 teachers of Science were approached by Ms Manyane at schools in 6 circuits ( 2 areas) of the Northern Province where Sepedi is the mother tongue of the majority of pupils (in $74 \%$ of the cases):

AREA

Warmbaths

\section{CIRCUIT}

Warmbaths

Thabazimbi 
Mahwelereng

$$
\begin{aligned}
& \text { Mahwelereng } \\
& \text { Mokopane } \\
& \text { Mapela } \\
& \text { Potgietersrus }
\end{aligned}
$$

The teachers were requested to fill in a questionnaire on the use of Science terms. This questionnaire was intended to be the first step in determining:
- the current status of Sepedi as an LSP for Science in predominantly Sepe- di-speaking areas, and
- the attitudes and perceptions of speakers regarding the terminologisa- tion of Sepedi, especially for the purpose of conceptualisation.

Each questionnaire was personally collected, and a 100\% response was obtained. This also meant that the sample could be regarded as representative from a geographical point of view. The results can be summarised as follows:

- $\quad 4 \%$ of the Science teachers indicated that they at least sometimes used the mother tongue of the pupils when teaching Science.

- The following reasons were given for occasionally reverting to the mother tongue:

to re-explain a concept which pupils had not understood through English $(96 \%)$,

to explain difficult concepts $(87 \%)$,

when performing experiments $(64 \%)$, and

to explain new concepts $(59 \%)$.

- According to $70 \%$ of the teachers, pupils responded better when mothertongue teaching took place.

- $\quad 76 \%$ of the teachers were of the opinion that pupils understood better when teaching took place in the mother tongue.

- Regarding the use of terminology when reverting to the mother tongue, $34 \%$ answered that they only used English terms; $62 \%$ stated that they used English terms for some concepts and mother-tongue terms for others; and only $2 \%$ indicated that they only used mother-tongue terms.

- There seems to be either uncertainty or indecisiveness among teachers regarding the deliberate coining of terms in the mother tongue: only $36 \%$ were in favour of term creation across the board; $52 \%$ were of the opinion that translation equivalents should only be created for some concepts; and 12\% said they would prefer that only English terms be used.

- Two thirds of the teachers $(66 \%)$ were of the opinion that pupils would prefer to be taught Science only in the mother tongue; $26 \%$ said that it would not matter to the pupils; and only $8 \%$ expressed the view that the pupils would reject mother-tongue teaching. 
- Concerning the teachers' attitudes towards monolingual mother-tongue teaching of Science, $36 \%$ were strongly in favour of mother-tongue teaching of Science; $42 \%$ were in favour of transferring the responsibility - in particular to the pupils $(14 \%)$; the parents $(30 \%)$; or the principal $(8 \%)$. Only $12 \%$ were strongly opposed to mother-tongue teaching of Science.

- A comparable response was received on the question relating to teachers' attitudes towards the option of pupils being formally evaluated in the mother tongue: $34 \%$ reacted strongly positive; $30 \%$ cautiously positive; and $36 \%$ were opposed to any change from the status quo.

Although the majority of teachers admit that the use of the mother tongue plays a significant role in the teaching of Science, especially in concept-formation and understanding, and express fairly positive feelings towards mother-tongue teaching and learning, they are hesitant to unconditionally support terminologisation in the mother tongue. Holistically interpreted, the results suggest that the hesitation might be due to the fact that empowerment through English as well as international participation are valued extremely highly, and that monolingual mother-tongue teaching or evaluation might jeopardise the freedom only recently won after apartheid.

These attitudes seem to correlate with attitudes in higher education circles, although the views of the latter are expressed in a more covert way. In the FRD's annual magazine Scientech (1998: 3), an article "Places for Children's Minds to Play", dealing with the work of the Setlhare Science Curriculum Trust (a body based at the University of the Witwatersrand and concerned with the development of materials and methods for the teaching and learning of Science), confirms my observation that educators demonstrate a growing openness towards alternative teaching models. The contribution closes with the following summary of research done by the Curriculum Trust:

The study did not attempt to analyse the relationship between the students' multilingual dialogues and their learning of science. But it did suggest that there was a need for research to investigate the dominant assumption that science can and should be learnt in English only.

It does however seem as if there is caution not to allow language to become the central issue. Although language is perceived to be an important aspect of all teaching, the approach is pragmatic: facilitating understanding through the language the student knows best, but promoting proficiency and communication skills in the language of wider communication. This seems to be the view expressed in another article published in the same edition of Scientech (1998: 1011), entitled "Practical Solutions for Today's Classrooms". The article describes a project initiated by a team of microbiologists from the University of Cape Town to develop a theoretical and practical training course for secondary school Biology teachers. After a very successful pilot course offered in 1997, the project 
team planned to publish a Biology teachers' practical handbook in which the teaching approach and methodologies tested in the course were expounded. As far as the approach to language is concerned, the writer of the Scientech article says: "The book is also sensitive to the fact that teachers and students may speak many languages and that learners need to reach understanding in their first language and express this in the dominant classroom language."

An important question to ask is, however, whether a lenient approach towards language of instruction and classroom language will be acceptable to parents and pupils. Evidence described in paragraph 4 below is not favourable in this regard.

\subsection{Existing corpus of Science terms in Sepedi}

In order to find an empirically justified answer to the research question on the scope and nature of the existing corpus of Science terms in Sepedi, it was decided to compile a second questionnaire containing the Science terms in the glossaries of the English text books for Physical Science (Grades 11 and 12). Twenty respondents from the Warmbaths and Mahwelereng areas of the Northern Province, each with more than five years experience of teaching Science, were requested to supply translation equivalents in Sepedi.

The translation equivalents ${ }^{2}$ supplied by the respondents may be grouped into roughly four categories: indigenous, morphologically simplex or complex translation equivalents; transliterations; possessive constructions (containing two nouns combined by the possessive conjunctions $w a, b a, y a, l a, a, s a t 5 a, b j a$ or $g a$, often used to translate English or Afrikaans compounds); and longer circumlocutions.

\section{(a) Indigenous equivalents}

Only the following indigenous equivalents (morphologically simplex or complex) were supplied ( 30 out of $240=12 \%$ )

ENGLISH
absolute zero
acceleration
addition reaction
alkanol (alcohol)
allotrope
analyser
antinode
balanced forces
bond energy

\section{SEPEDI}

lefeelafeela

koketšlebelo

tlhakantšhophetogo

setagi

thlagontši

sentšhadikarolwana

makopanelo-lephotong

*maatlatekatekanyo ${ }^{3}$

maatlatomagano 


$\begin{array}{ll}\text { catalyst } & \text { setlhotlholetši } \\ \text { current } & \text { "mohlagase } \\ \text { distance } & \text { bokgole } \\ \text { dynamics } & \text { *diphetogo } \\ \text { energy } & \text { maatla } \\ \text { force } & \text { maatla (dikgoka) } \\ \text { frequency (of force) } & \text { "kgafetšakgafetša } \\ \text { gradient } & \text { motheosa } \\ \text { half reaction } & \text { seripaphetogo } \\ \text { indication } & \text { sebontšhi / sešupi } \\ \text { inert } & \text { seganaphetogo } \\ \text { kinetic energy } & \text { maatlamosepelo } \\ \text { mass } & \text { boima } \\ \text { period } & \text { nako } \\ \text { phase } & \text { seemo } \\ \text { photon } & \text { lehlasedi } \\ \text { principle } & \text { mokgwa } \\ \text { speed } & \text { lebelo } \\ \text { wave } & \text { lephoto }\end{array}$

\section{(b) Transliterations}

Transliterations were much fewer than expected (only 10 out of $240=4 \%$ ):

ENGLISH
alkanes
alkenes
alkynes
atom
base
electron
halo-alkane
hydro-carbon
hydrogen
ion

SEPEDI
alekane
alekenes
alekaines
atomo
beisi (motheo, botlase)
eleketerone
halo-alikane
haedro-khabone
haedrogene/hydrogene
ayone

The low percentage of transliterations may be ascribed to the following:

- Science teachers may in general not be sensitive to language issues and may not always realise when they are making phonological adaptations.

- The English terms in the original English list are mostly multiword terms or compounds consisting of more than two morphemes. It is to be expected that these complexes will be translated by circumlocutions or 
hybrid circumlocutions (containing Sepedi elements as well as English elements or transliterations), e.g. esiti ya Arrhenius (Arrhenius acid); boima bja atomo (atomic mass).

A list of Sepedi terms compiled independently by a Science teacher in the Northern Province supports this hypothesis (see paragraph 4 below), as his corpus contains more transliterations, e.g.:

\begin{tabular}{ll} 
ENGLISH & SEPEDI \\
acid & esiti \\
aluminium & aluminiamo \\
anion & anayone \\
base & peisi \\
carbon & khabone \\
carbonate & khabonate \\
carbonic & khaboniki \\
cation & katayone \\
chemical & sekhemise (khemikale) \\
chemistry & khemistiri \\
compound & kompo \\
copper & koporo \\
electron & elektrono \\
element & elemente \\
gas & gase \\
hydrogen & hydrogene \\
ion & ayone \\
molecule & molekule \\
oxygen & oksegene \\
proton & protono \\
silver & silibere \\
sodium & sodiamo \\
temperature & themperetsha \\
tin & thine \\
vector & fektoro \\
& \\
\hline &
\end{tabular}

Transliteration as a mechanism for term-formation brings to the fore a deeprooted philosophical controversy. This difference of opinion centers around the need to make international information accessible (in a non-international language) in the most "internationalised" form, versus preserving the language and keeping it pure (cf. French and King 1997: 89; Cluver 1997: 110). 


\section{(c) Possessive constructions}

Possessive phrases, consisting of two nouns combined by a possessive conjunction, were found to be quite prolific, e.g.:

ENGLISH
absorption spectrum
alkali metal
Arrhenius acid
Arrhenius base
atomic mass
atomic number
Balmer series
Boyle's law
cell potential
clock reaction
conservation of energy
crystallography
Dalton's law
Fraunhofer lines
gravitation
Hund's rule
Huygen's principle
hydrogen bond
interference
Le Chatelier's principle
mass number
octet rule
Ohm's law
phase equilibrium
refraction
terminal velocity
wave length

SEPEDI
nweletso ya mebala
tshipi ya alkali
esiti ya Arrhenius
beisi ya Arrhenius
boima bja atomo
palo ya atomo
tatelano ya Balmer
molao wa Boyle
maatla a lelahla
tiragalo ya nako
polokego ya maatla
thuto ya momagano
molao wa Dalton
methaladi ya Fraunhofer
maatlakgogedi a lefase
molao wa Hund
mokgwa wa Huygen
tomagano ya hydrogen
thulano ya maphoto
mokgwa wa Chatelier
nomoro ya boima (palo ya boima)
molao wa seswai
molao wa Ohm
tekatekanyo ya seemo
kobego ya mahlasedi
lebelo la bofelo
botelele bja lephoto

Despite the instruction to respondents (by Carstens and Manyane) not to supply meanings instead of translation equivalents, many verbose translations were given. This may either imply that teachers tend to circumvent the lack of terminology by using circumlocutions or that circumlocutions are often used with the deliberate purpose of explaining the meaning of an opaque English term during a Science lesson. Compare the following examples: 


$\begin{array}{ll}\text { ENGLISH } & \text { SEPEDI } \\ \text { capillarity } & \begin{array}{l}\text { go hlatloga goba go theoga ga meetse ka gare ga peipi } \\ \text { a dirwa ke kgogedi magareng ga meetse le peipi } \\ \text { taetšo ya couper ya go laetsa dikarolwana tsa atomo } \\ \text { tša go sepetsa mothagase } \\ \text { phetogo yeo e lego gore maatla a yona a gogwa gore } \\ \text { phetogo e tšwelele pele }\end{array}\end{array}$

Significantly fewer circumlocutions occur in the list compiled by Pare (paragraph 4). This may indicate that the compiler was aware of the requirements for term status (a measure of conventionality, length restriction, etc.), or that he relied on the translation equivalents found in dictionaries and other normative sources, along with those supplied by pupils at his request.

\section{The work of P.T. Pare and F. Ntake}

\subsection{Background}

In the discussion of the research done by Manyane and Carstens I referred to terms collected by P.T. Pare. Pare (personal correspondence by e-mail) taught Science in English to Std. 5 (Grade 7) pupils from 1985 to 1993. During this time he realised that the "lack of involvement in class discussions was due to insufficient command of the language of instruction" and that he was using much of the time in Science classes trying to explain basic English expressions. He also noticed that the results were appalling whenever a descriptive answer was required from pupils during a test or an examination.

From 1991 onwards, he started recording translation equivalents for English terms by consulting his students as well as English-Sepedi and AfrikaansSepedi dictionaries. Only in 1997 did he try to teach bilingually through English and Sepedi to a Std. 2 and a Std. 5 class in St Mark's College at Jane Furse. Together with Fanuel Ntake, a teacher of Physical Science at a secondary school in the Northern Province, he started translating matric examination papers for Chemistry. The reason for this was, among others, to indicate that Sepedi had the terminology necessary to serve as a vehicle for conveying the content of the subject field. The papers in Sepedi (Higher and Standard Grade) translated by Pare and Ntake are currently being reviewed by the Education Department of the Northern Province, and feedback has also been invited from other stakeholders and interest groups.

Pare is convinced that the pupils respond much better when he communicates in Sepedi during Science lessons. However, strong resistance has been encountered from parents. According to him (personal communication by email) "they are worried that Science taught through Sepedi is not proper Science". At a secondary school in Marishani in the Northern Province, where he taught Science to matric pupils, even his fellow teachers and the school princi- 
pal were against his teaching in Sepedi, and put considerable pressure on him to use English only in the classroom. Resistance also came from the parents. Pare expressed their attitude as follows:

Parents generally feel that a good command of English is so essential for their children's success in the modern world that every opportunity must be used to expose them to English. They are unaware of recent linguistic research which shows that the prior acquisition of advanced cognitive processing skills in the mother tongue actually facilitates the acquisition of the second language.

\subsection{The corpus}

Pare's corpus consists of approximately 500 terms. Not all of them are restricted to the domains of Chemistry and Physics. Some are words with general as well as terminological meanings (polysemic or homonymic words of which one or more meanings are terminological meanings), words belonging to the general academic vocabulary, and mathematical terms. When compared to the data collected by Manyane and myself in the Mahwelereng and Warmbaths areas there seem to be similarities as well as differences. Transliterations make out approximately $15 \%$ of Pare's corpus, which is a much higher percentage than recorded in our survey. Moreover, the number of indigenous equivalents recorded by us seem to be significantly fewer than those recorded by Pare. As suggested above, the higher percentage of simplex and complex indigenous equivalents as well as transliterations in Pare's corpus may be ascribed to a deliberate attempt at secondary term-formation rather than to a detailed explication of meaning. Moreover, Pare seems to be making a serious attempt to adapt Sepedi for use as a fully-fledged LSP for Science so that it can take its place at the same level as English. The teachers interviewed by Manyane in the Mahwelereng and Warmbaths area, on the other hand, seem to use Sepedi to explain or disambiguate English terms and expressions. Circumlocutions would serve the purpose better than terminological equivalents in the mother tongue, and as suggested above, this might be the reason for the proliferation of lengthy "definitions" supplied by respondents instead of terminological equivalents.

\section{Conclusion}

My firm conviction is that the evidence resulting from the attitude survey by Carstens and Manyane, the field work by Manyane, Pare and Ntake's experience with teaching through Sepedi, and Pare's comprehensive term list all signify a clear "go ahead". Educators now seem to be realising the advantages of a 
more flexible language policy in the classroom, and that true democracy is being able to use the language one knows best in all possible contexts. Teachers also seem to agree that a pragmatic approach such as "use what you have" is good for language development.

This does however not mean that more research is superfluous. Additional field work is still necessary to elicit the entire stock of terms for special-field concepts that have already acquired term status in the African languages by virtue of their use, inter alia in the classroom situation. It is also necessary to put Sepedi examination papers to the test. The results then need to be compared to those of pupils of similar potential who have written the corresponding English paper. If the results of those who wrote the Sepedi paper are significantly better, a deliberate attempt should be made to convince students, parents and school principals that mother-tongue teaching of content subjects is a step forward and not backward.

The standardisation of Science terms in Sepedi should be encouraged and accelerated in the meantime by recording existing terms in term banks, publishing them in the form of bi- or multilingual term lists and dictionaries, distributing these in schools, and also requesting feedback from all stakeholders: pupils, parents, teachers and principals. The ideal would be for definitions to be supplied in English as well as in the relevant African languages. This will ensure that the learner who speaks an African language will be able to access knowledge via the language he/she knows best, yet remain in close contact with the language(s) used internationally within scientific and economic domains (i.e. English).

\section{Notes}

1. The hypothesis that language is one of the most important stumbling blocks in gaining access to the natural Sciences is verified by a survey that Kwesi K. Prah undertook in 1992 among university students of Botswana, Namibia, Swaziland, the Western Cape, the Transkei and Lesotho (Prah 1995).

2. Translation equivalents given between brackets are alternatives which have been suggested by a mother-tongue speaker invited to comment on the list.

3. Translation equivalents marked with an asterisk were regarded as either too general in meaning or too non-specific by a mother-tongue speaker invited to comment on the list.

4. According to Sager (1990: 80) secondary term-formation occurs when a new term is created for a known concept, either

(a) as a result of the transfer of knowledge (especially scientific and technological knowledge) to another linguistic community - as in the case of many European and Asian languages, and now also the African languages; or

(b) as a result of revising a terminology or specific terms of that terminology. 


\section{References}

Bekeweni, Z. 1997. Standardisation of the Vernacular. National Terminology Services. 1997: 91-95.

Carstens, A. 1997. The Compilation of a Multilingual, Explanatory Dictionary of Chemistry for South African Students. Lexikos 7: 1-24.

Carstens, A. 1998. On Justifying the Compilation of a Multilingual, Explanatory Dictionary of Chemistry. S.A. Journal of Linguistics 16(1): 1-6.

Chumbow, B.S. 1990. The Place of the Mother Tongue in the National Policy on Education. E.N. Emenanjo (Ed.). 1990. Multilingualism, Minority Languages and Language Policy in Nigeria: 6172. Agbor: Central Books in Collaboration with the Linguistic Association of Nigeria.

Cluver, A.D. de V. 1989. A Manual of Terminography. Pretoria: Human Sciences Research Council.

Cluver, A.D. de V. 1987. A Sociolinguistic Approach to the Study of Technical Languages. Logos 7(2): $13-30$.

Cluver, A.D. de V. 1996. Language Development. LANGTAG Subcommittee on the Development of (South) African Languages. 1996: 1-12.

Cluver, A.D. de V. 1997. Summary. National Terminology Services. 1997: 109-114.

French, E and M. King. 1997. Literacy. National Terminology Services. 1997: 85-89.

Joubert, M. (Managing Ed.). 1998. Places for Children's Minds to Play. Scientech '98: 2-3.

Joubert, M. (Managing Ed.). 1998. Practical Solutions for Today's Classrooms. Scientech '98: 10-11.

LANGTAG Subcommittee on the Development of (South) African Languages. 1996. Issues in Language Development: Focusing on The Future of the Apartheid Language Boards and The Harmonisation and Development of African Languages. Pretoria: Department of Arts, Culture, Science and Technology.

Manyane, S.M. 1998. Die gebruik van wetenskapsterminologie in die senior sekondêre fase. Unpublished mini-dissertation for the M.A. degree (by coursework). Pretoria: University of Pretoria.

Matšela, Z.A. 1987. The Problems of Modernising the Development of Sesotho Scientific/Technical Terminologies. Logos 7(2): 79-88.

Mohapi, T.W.D. 1997. Education in Relation to African Languages. National Terminology Services. 1997: 75-80.

Mthembu, P. 1997. Standardisation of the Vernacular. National Terminology Services. 1997: 97-99.

National Terminology Services. 1997. The Feasibility of Technical Language Development in the African Languages. Papers presented at the Human Sciences Research Council, Pretoria, on 8 March 1996. Pretoria: Department of Arts, Culture, Science and Technology.

Ngubane, B.S. 1997. Opening Address. National Terminology Services. 1997: 7-9.

Prah, Kwesi K. 1995. Mother Tongue for Scientific and Technological Development in Africa. Bonn: German Foundation for International Development Education, Science and Documentation Centre.

Prah, K.K. 1997. The Language Factor in the Scientific and Technological Development of Africa. National Terminology Services. 1997: 21-38.

Sager, J. 1990. A Practical Course in Terminology Processing. Amsterdam: Benjamins.

South African Govemment. s.a. Green Paper on Science and Technology. Pretoria: Government Printer. 